\title{
LEAN STRATEGY IMPLEMENTATION TO IMPROVE THROUGHPUT IN ASSEMBLY LINE: DUL-DB21SSC MANUFACTURING PROCESS AT PT X
}

\author{
Gemma Eka Santoso; Gita Ayu; Nike Septivani \\ Industrial Engineering Department, Faculty of Engineering, Binus University \\ Jl. K.H. Syahdan No. 9, Palmerah, Jakarta Barat 11480 \\ KGayu@binus.edu
}

\begin{abstract}
Lean production has dramatically lifted the competitiveness of many manufacturing companies and the value they deliver to customers. This project examines the benefit of balancing process and workstation arrangement of dogbone damper in an order that maintains a smooth flow of materials and component through the process. The analysis begins from calculating takt value to establish the required rate of production. From here, any total cycle time exceeding takt time is called a bottleneck process and should become a target of the improvement. Next, arranging people and equipment into cells has great advantage in terms of achieving lean goals. One advantage of cells is the one-piece flow concept, which states that each product moves through the process one unit a time without sudden interruption, at a pace determined by the customer's need.
\end{abstract}

Keywords: lean strategy, process, takt

\begin{abstract}
ABSTRAK
Produksi ramping secara dramatis mengangkat daya saing perusahaan manufaktur banyak dan nilai yang mereka berikan kepada pelanggan. Proyek ini meneliti manfaat dari proses balancing dan pengaturan workstation damper dogbone yang mempertahankan kelancaran arus bahan dan komponen melalui proses tersebut. Analisis dimulai dari menghitung nilai takt untuk menetapkan tarif yang diperlukan produksi. Dari sini, setiap waktu siklus total yang melebihi waktu takt dianggap sebuah hambatan dan harus menjadi target perbaikan. Selanjutnya, pengaturan orang dan peralatan ke dalam sel memiliki keuntungan besar dalam hal mencapai tujuan penghematan biaya. Salah satu keuntungan dari sel adalah one-piece flow konsep, yang menyatakan bahwa setiap produk bergerak melalui unit satu proses waktu tanpa gangguan seketika, pada kecepatan yang ditentukan oleh kebutuhan pelanggan.
\end{abstract}

Kata kunci: strategi ramping, proses, takt 


\section{INTRODUCTION}

PT X have supplied Type Tested Line \& String Hardware for 150, 275, 400 \& 500 kV system (international standard products for the electrification system) for Indonesia \& export projects to UK, USA, South America, Europe, Middle East, and S.E Asia. One of their main products was called dogbone.

Comparing with all products that have been manufactured in the company, casting gets the highest sales percentage (Figure 1).

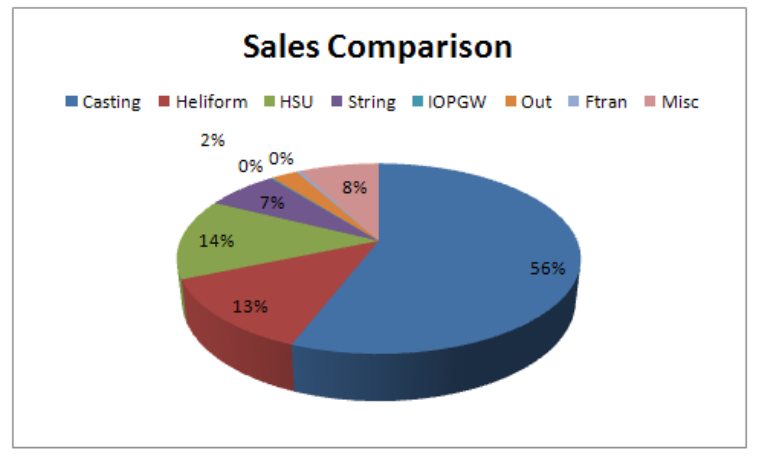

Figure 1 Sales comparison (last 3 years)

Figure 2 shows that among all of casting products, dogbone got the highest sales of the year and profit gained from this product is quite promising (40\% profit from selling price). Therefore, this product is chosen as a target of the improvements.

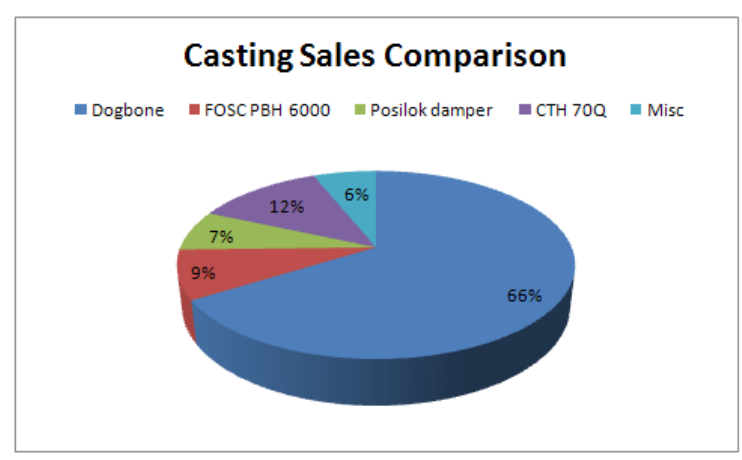

Figure 2 Casting sales comparisons

Sales department claimed that dogbone demand approximately can reach 20,000 pcs per month while their capacity only can produce $16,000-17,000$ pcs. At that time increasing capacity still not necessary since unmeet demand can be solved by doing overwork.

On the latest of 2007, PT X now became a major manufacturer of dogbone damper for global supply to its parent firm. Increasing demand should be balanced with increasing production capacity. This condition makes the management put their best effort on increasing capacity to fulfill the future demand. 
There are two choices in increasing the production capacity either perfecting the manufacture processes or purchasing a new machine. Before buying a new machine as the final decision, perfecting the current process is a must and become a major concern for the engineer to make possible improvements. Implementing lean strategy is chosen as a good way to reduce non-added value which leads to process perfection.

In general dogbone manufacturing process are divided into five main categories: hook production process, keeper production process, collet production process, messenger cable production process and assembly process. Hook, keeper, collet, and messenger cable are the components of dogbone and all of those components will be assembled until it turns into finish goods.

In order to find the right process to be improved, all of the processes is listed compared. Bottleneck process from each category is evaluated and the result can be shown on Figure 3. Assembly process has the highest cycle time so it will be the main concern to be improved.

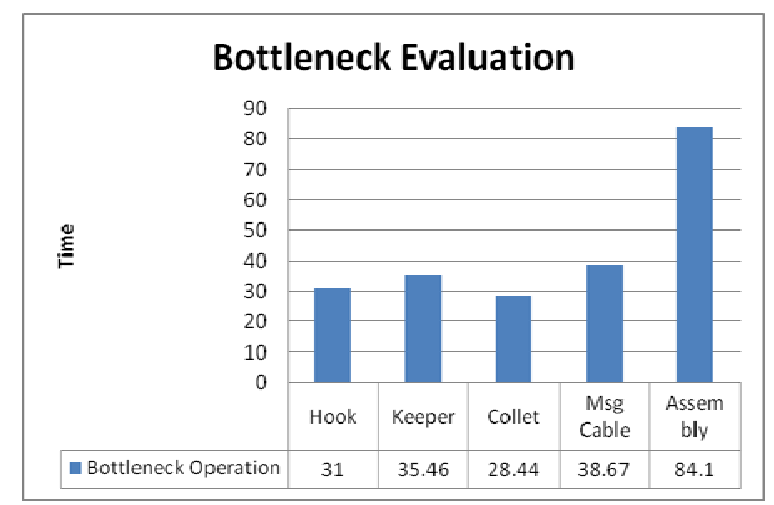

Figure 3 Bottleneck evaluation

To approach the problem itself, lean strategy will be used since it will bring the flexibility, high quality, shorter lead times, and lower costs which are very essential for the companies itself. (Sheldon, Donald H., 2005). In lean methodology there is a fundamental difference to the traditional methodology of data collection, analysis and making decisions. The method is formalized in lean environment. Everybody will share the same way of data collection and hence will have the same information to begin with.

On the other hand lean tools are very simple. For an example "Go and See It for Yourself" approach reduces the need for complex data collection techniques and gives the first hand experience to the people who try to analyze the problem. Ask "Why" 5 times is another simple and important tool to find the cause to the problem. Collectively these processes and tools provide a formalized, standard and simple way to analyze problems, finding root cause and making decisions. All the parties involved will share the same information throughout. This makes it is very easy to implement decisions made. Importantly in the lean process of problem solving, analysis ends with decisions, unlike in many traditional organizations that end in "analysis and paralysis" scenario.

\section{METHOD}

The first step to approach the problem is by observing current situation in PT X. Information can be collected through visual condition, data collections, or even workers opinion. In this step, 
problems are clarified and goals should be set. When a problem still cannot be found, a better analysis on the current condition should be done to recognize where the problem is.

A tools or method can be really helpful in fixing the problems. An examination to the objectives is necessary to choose the most likely lean tools / method to apply. If the tools are not good enough to solve the problem, other tools may be considered. From here, get more information and data to support the analysis stages.

To approach a problem, there are often many options as to the problem's root cause. One way to capture these different ideas and stimulate the brainstorming on root causes is the cause and effect diagram, commonly called a fishbone. The fishbone will help to visually display the many potential causes for a specific problem or effect.

Analyze the data to fix the problem and find opportunities to make some possible solutions. Then the solutions are compared to get the best decisions to solve the problem. The result or the summary will represent the best solution that has been chosen by the writer and will be purposed to the company.

\section{RESULTS AND DISCUSSION}

\section{Problem Identification}

In an effort on optimizing capacity, potential waste that can be eliminated are investigated and analyzed. Figure 4 is the cause and effect diagram of the problem:

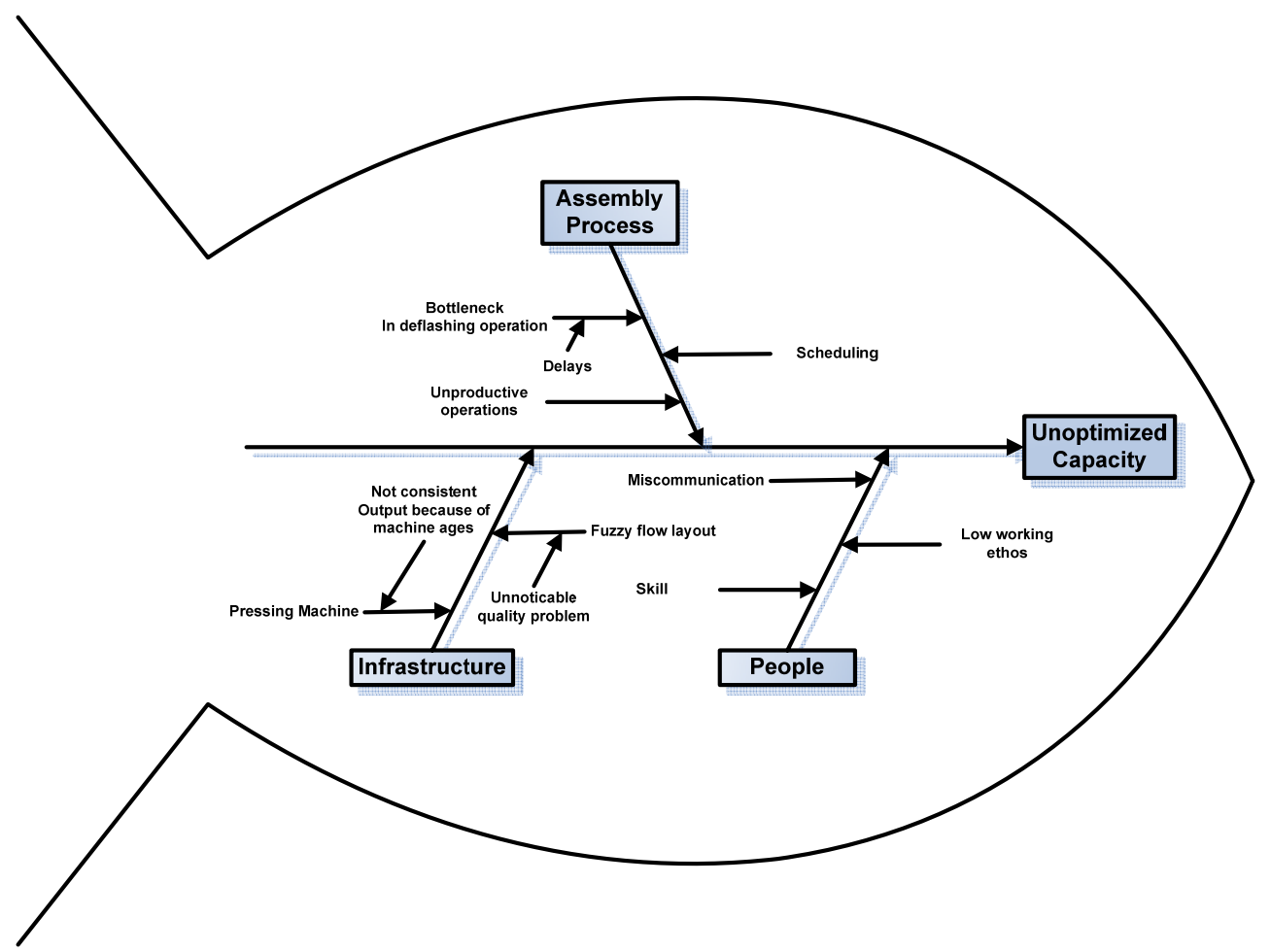

Figure 4 Fishbone diagram 


\section{Bottleneck Operation in Deflashing Process}

Big variance in the processing time for each workstation can create a potential bottleneck in the process. A bottleneck might be occurred when a workstation cannot produce fast enough to meet the required takt time.

Takt time is calculated by following formula (Costanza, J., 1994):

$$
\text { Takt Time }(\mathrm{TT})=\quad \frac{\text { Available work time }}{\text { Customer demand }}
$$

Therefore data is taken to calculate takt time value. Table 1 gives the total available work time in one month.

Table 1 Available Work Time Calculation

\begin{tabular}{|l|l|l|}
\hline Working hours / shift & 7 & hrs \\
\hline Shift & 3 & shift \\
\hline Work days & 5 & days \\
\hline Available Time in 1 month & $420 \quad 1,512,000$ & sec \\
\cline { 2 - 3 } & \multicolumn{2}{|l|}{}
\end{tabular}

Sales department claimed that dogbone demand approximately can reach 20,000 pcs per month even their capacity only can produce $16,000-17,000$ pcs.

$$
\begin{aligned}
\text { Takt Time }(\text { TT }) & =\frac{1,512,000}{20.000} \\
& =75.6 \mathrm{sec}
\end{aligned}
$$

The chart in Figure 5 gives several insights as to what happening. First, deflashing process is a bottleneck because its cycle time is greater than the takt time. It cannot meet the rate of customer demand, and the company will be running this process on additional shifts, or operating it on overtime to keep up with production.

Surface checking (galmet) cycles close to the takt time, which may present problems in the future if the product grows (Takt time line drops). The other processes seem to have enough capacity for now.

From information above, concentration of improvement should be focused on deflashing process. The first step is to balance the process in order to reach an expected ideal condition (It does not matter whether it is only $90 \%, 95 \%$, or $100 \%$ ), because it is the aim of continuous improvements to reach a perfect condition from different resources and real condition in the shop floor. Next, every line balancing job should consider takt time value as a reference. This takt time value may shift from time to time, so line balancing job should be done continuously in some particular time.

\section{Unproductive Operation}

Unproductive operation means unnecessary process that will not add value to the product. In here researcher will focus on deflashing process. Deflashing process happens because the previous 
process (Collet crimping) is not completed perfectly. Collet crimping used pressing machine to press the collet onto the messenger cable and it will create flash which shown in Figure 6.

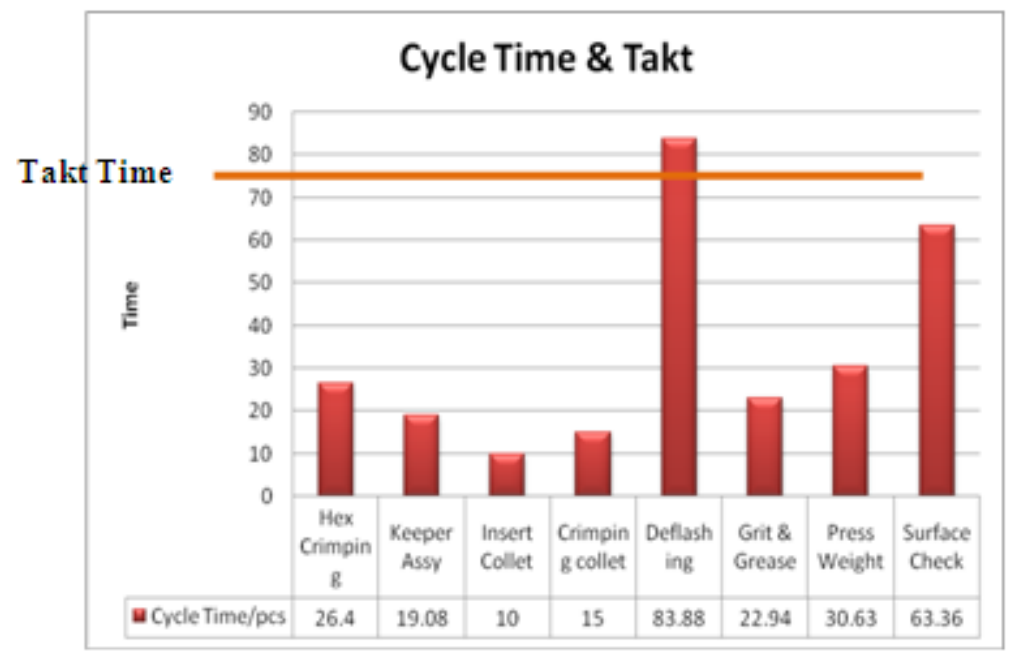

Figure 5 Cycles Time \& Takt Time

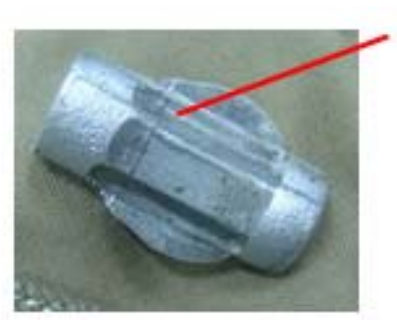

Flash

Figure 6 Flash on collet

\section{Scheduling}

Scheduling problems may disturb components availability and caused longer lead time, larger WIP, productivity and throughput capability reduced, etc (Nahmias, S., 2008). However, focusing in scheduling problem in a project-oriented environments company may be complicated and need a careful thought since it was characterized by complex projects with strict individual deadlines.

\section{Plant}

Almost all machines in PT X were bought when it was established at the first time (in 1997). In addition, some machine is given from their sister company (Parent Firm) which also not new. As we know, the more the age of a machine, the more it cannot keep the consistency of output.

Machines are grouped by function since various types of product are manufactured. There are manual operating machines such as casting station, drilling machine, linishing machine, bandsawing machine, pressing machine, crimping machine, rumbling machine, etc. In the heliform sections there are forming machine, winding machine, gluing machine, etc. 
Present state shows that the process flow on DUL-DB242BSSC is poor. Space limitation and management policy are some possible reasons that make the problem happened. Space limitation - in the past, after the layout has been arranged, new machine was placed in available area in the shop floor. One of the examples is the pressing machine located near the heliform area. Management policy - some machine is located in a special place because of the management policy. The reason is to provide good, safe, comfortable working conditions for the operator. For example, bandsaw area for cutting messenger cable was located at the back because it was dangerous. Rumbler was located at the back also since it is too noisy. If this machine was placed inside the shopfloor area, there are possibilities to distract and annoy the employee. When employees are distracted, they cannot give their maximum performance and fatigue will result.

To minimize the transportation time, the company uses batch processing flow system. However batch processing flow system can leads to sub-optimal behavior (Hopp, W.J. and Spearman, 1996). One operation may be greatly improved without improving the overall system performance. And it will reduce the motivation to improve. For example: there are problems in equipment $\mathrm{A}$, but the workers doesn't worry about preventive maintenance on it since they think that overtime can make up for any lost production. Another example is a defect produced by a process is not noticeable until someone tries to complete the next process. By that time, there may be weeks of bad parts in the process.

\section{Problem Solving}

PT X now became a major manufacturer of dogbone damper for global supply to its parent firm. Therefore the opportunity of increasing demand should be balanced with increasing production capacity. It makes the company wants to double their maximum capacity. Implementing lean strategy, the improvements effort will concentrate on waste elimination which leads to process perfection.

\section{Bottleneck Operations}

Sales department claimed that dogbone demand approximately can reach 20,000 pcs per month while their capacity only can produce $16,000-17,000$ pcs. At that time increasing capacity still not necessary since unmeet demand can be solved by doing overwork. To calculate current takt value, the demand was set for 20.000 to show where bottleneck is about to occur.

$\begin{array}{ll}\text { Demand } & : 20.000 \mathrm{pcs} \\ \text { Takt Time } & : 75.6 \mathrm{sec}\end{array}$

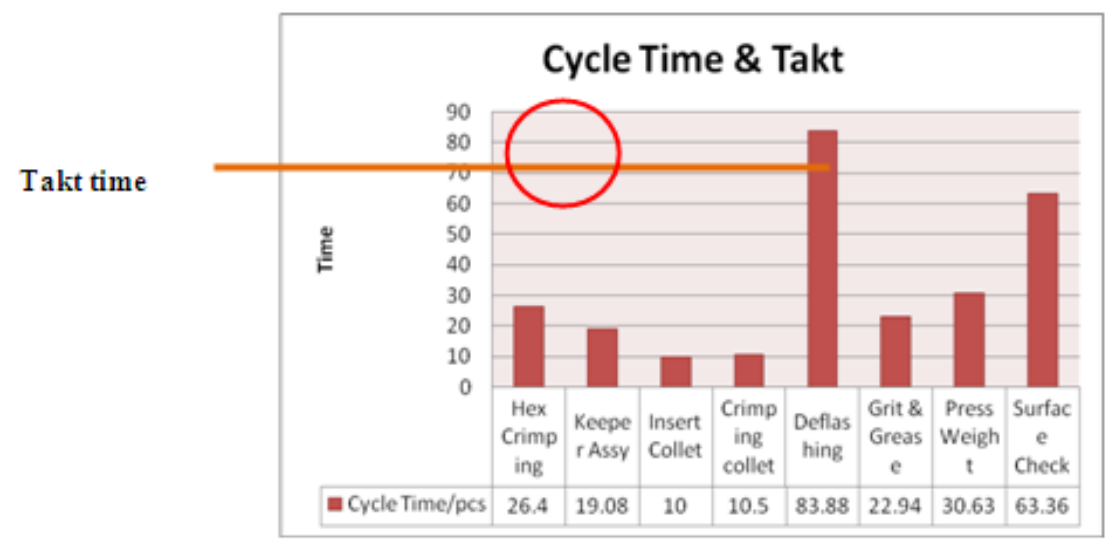

Figure 7 Takt value on current condition 
From figure 7, major concern for improvement is on the deflashing process. As the objective of this thesis is to double production throughput, now we set the demand to 32.000 , therefore takt time calculations:

$$
\text { Takt Time }(\text { TT })=\frac{\text { Available work time }}{\text { Customer demand }}
$$

Table 2 shows the available work time for one month.

Table 2 Available Work Time Calculation

\begin{tabular}{|l|l|l|}
\hline Working hours / shift & 7 & hrs \\
\hline Shift & 3 & shift \\
\hline Work days & 5 & days \\
\hline Available Time in 1 month & $420 \quad 1512000$ & hrs \\
\cline { 2 - 3 } & \multicolumn{2}{|c|}{ sec } \\
\cline { 2 - 3 }
\end{tabular}

$$
\begin{aligned}
\text { Takt Time }(\text { TT }) & =\frac{1.512 .000}{32.000} \\
& =47.25 \mathrm{sec}
\end{aligned}
$$

When takt time line drops as illustrates in figure 8, now surface checking (galmet) cycle also become a problem since it cannot meet the rate of customer demand. The other processes seem to have enough capacity for now.

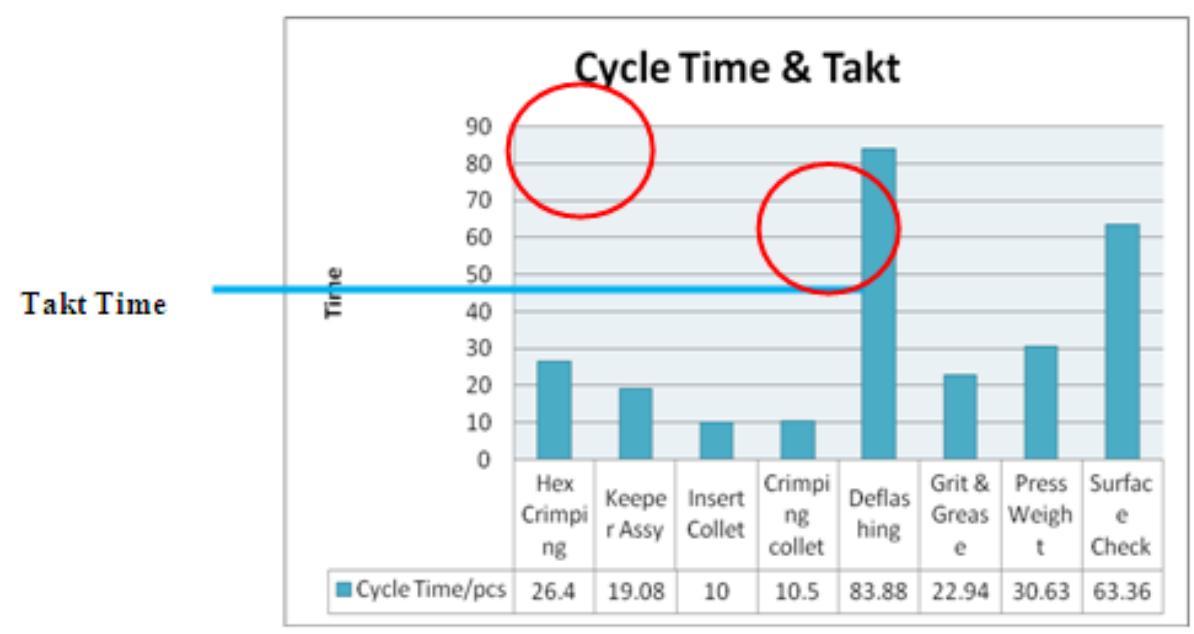

Figure 8 Targeted takt value

\section{Deflashing}

Deflashing process is the process to linish flash from collet. Flash is a residue created from a material when it was punched by pressing machine. Therefore, an effort to eliminate the deflashing process is made by improving the previous process (crimping).

There are 2 steps in improving the crimping process: (1) change the pressing method originally, two sides flat crimping type was used to assemble collet on messenger cable. To reduce the 
flash size, flat crimping method is changed become hexagon crimping; (2) improving dies - after some consideration, a trimming process will be added to remove the flash from collet. This trimming process is done in the same machine with the pressing machine.

After doing some trials on the workpiece, there are four types of dies that will be compared to get the best result of this idea. The design will be given to the supplier which will try the design and give the result to PT $X$.

\section{CONCLUSION}

In this research lean strategy is applied to eliminate waste in order to increase $50 \%$ of throughput capability to meet customer demand in the future. In order to optimize the production capacity, potential wastes that can be eliminated are investigated and analyzed. Efforts of improvements are focused on how to minimize the bottleneck problems and how to create a continuous production flow to keep pace with customer demand. (George, Michael L., 2002)

Takt time refers to targeted pace production and it should be the driver in developing the way the product is scheduled and the way material flows through the system. While this thesis objective is to increase production capacity from 16.500 pcs to 32.000 pcs per month, targeted takt time is shifted from 75.6 to 45.76 sec.

Apparently, bottleneck operation was found on deflashing process in assembly line. By perfecting the previous process, now deflashing process can be eliminated and the bottleneck operation is shifted to a lesser cycle time but it still fit within the targeted tempo.

To create a lean flow, all assembly processes are put in a cell. The main reason for this is by becoming leaner a great deal of space is actually freed up and it can bring dramatic reduction in inventory. Another benefit comes because of the shorter feedback loops, the quality is improved. Defect on components which is made this morning can be realized on the assembly time this afternoon instead weeks from now.

Based on data taken from October-December 2007, the average production shipment was approximately 16,000-17,000pcs dogbone damper/ month. After implementation, it can be shown that production shipment in February-May 2008 increased gradually until it reaches 24,000pcs dogbone damper/ month or it increases approximately $45 \%$ from its existing capacity. Actually target improvements were set for the maximum capacity of the line which is 32.000 pcs dogbone/ month to anticipate the increasing demand in the future.

\section{REFERENCES}

Costanza, J. (1994). The Quantum Leap in Speed to Market. Centennial: Jc-I-T Institute of Technology.

George, Michael L. (2002). Lean Six Sigma: Combining Six Sigma Quality and Lean Production Speed. New York: McGraw-Hill.

Hopp, W.J. and Spearman, M.L. (1996). Factory Physics: Foundations of Manufacturing Management. New York: Richard D. Irwin Company. 
Nahmias, S. (2008). Production and Operations Analysis ( $6^{\text {th }}$ edition). New York: McGraw-Hill.

Sheldon, Donald H. (2005). Class an ERP Implementation: Integrating Lean and Six Sigma. Florida: J. Ross Publishing. 